\title{
UPAYA MENINGKATKAN KETERAMPILAN BERMAIN BADMINTON MENGGUNAKAN METODE DRILL PADA SISWA KELAS VI SD NEGERI 104213 DELITUA
}

\author{
Mariah Marlan \\ Surel: mariahmarlan@gmail.com
}

\begin{abstract}
ABSTRAK
Penelitian ini bertujuan untuk meningkatkan keterampilan siswa dalam bermain badminton melalui metode drill pada siswa kelas VI SD Negeri 104213 Delitua tahun pembelajaran 2014/2015. Penelitian ini menggunakan teknik non tes berupa unjuk kerja melalui kegiatan observasi, wawancara, dan dokumentasi foto. Dari hasil kegiatan pembelajaran yang telah dilakukan selama dua siklus dan berdasarkan seluruh pembahasan serta analisis yang telah dilakukan dapat disimpulkan sebagai berikut: 1) Meningkatkan keterampilan dalam bermain badminton. 2) Peningkatan prestasi olah raga badminton dilihat dari kemampuan siswa dalam melaksanakan dan mempraktekkan teknik-teknik dasar dalam permainan badminton. 3) Mempunyai pengaruh positif bagi perkembangan psikomotorik siswa.
\end{abstract}

Kata Kunci: Metode Drill, Badminton, Olah Raga

\section{PENDAHULUAN}

Pendidikan

Jasmani

merupakan media untuk mendorong perkembangan keterampilan motorik, kemampuan fisik, pengetahuan, penalaran, penghayatan nilai (sikap, mental, emosional, spiritual, dan sosial), dan pembiasaan pola hidup sehat yang bermuara untuk merangsang pertumbuhan, serta perkembangan yang seimbang.

$$
\begin{aligned}
& \text { Seiring dengan } \begin{array}{r}
\text { semangat } \\
\text { kehidupan }
\end{array} \\
& \text { berbangsa dan bernegara, pendidikan } \\
& \text { jasmani memiliki peran nyata dalam } \\
& \text { mendidik kader-kader bangsa yang } \\
& \text { sehat jasmani dan rohani. Kesehatan } \\
& \text { jasmani maupun rohani merupakan } \\
& \text { modal awal yang sangat menentukan }
\end{aligned}
$$

dalam persaingan global yang ketat. Kemajuan suatu bangsa diukur dengan seberapa besar angkat harapan hidup masyarakatnya, angka harapan hidup sangat dipengaruhi kualitas kesehatan yang dimiliki bangsa tersebut.

Pendidikan yang cenderung mengutamakan prestasi akademis semata tidak akan memberikan hasil maksimal pada perkembangan suatu bangsa. Selebihnya antara bidang akademis dan jasmani harus seimbang supaya memberikan kontribusi yang maksimal bagi bangsa dan negara. Jika dunia pendidikan masih mengabaikan akan pentingnya pendidikan jasmani tidak menutup kemungkinan kader-kader

Guru SD Negeri 104213 Delitua 
penerus bangsa akan menjadi generasi yang sangat rapuh. Generasi unggul adalah generasi yang tahan uji dalam menghadapi setiap problematika yang dihadapi, baik secara fisik dan mental.

Prestasi di sekolah juga dapat dipacu melalui prestasi dibidang jasmani. Melalui kegiatan olah raga siswa dapat menyalurkan bakat dan emosinya secara terarah. Dalam kegiatan ini siswa akan belajar bagaimana bekerjasama pada sebuah tim, bagaimana harus memenangkan persaingan secara sportif, bagaimana mengahargai sebuah kemenangan dan kegagalan. Guru dapat membantu siswa menyalurkan minat dan bakatnya supaya mencapai suatu prestasi tertentu. Dalam kegiatan olah raga semacam ini akan membantu proses berpikir siswa secara aktif dan sehat jika dibandingkan dengan kegiatan yang hanya diam di kelas mendengarkan materi.

Cabang olahraga sangat banyak jumlahnya namun salah satunya yang paling populer di Indonesia adalah permainan badminton. Permainan ini tidaklah asing bagi kalangan tua maupun muda di seluruh pelosok Indonesia. Apalagi di daerah permainan ini tidak sekedar ajang olah raga prestasi namun juga menjadi suatu hiburan yang bersifat murah meriah dan menyehatkan. Maka tidak heran apabila olah raga ini sangat dicintai dan mendapat tempat tersendiri di masyarakat.

Sejak pertama kali dilombakan di ajang Olimpiade 1992 di Barcelona atlet-atlet badminton Indonesia berhasil memperoleh mendali emas di semua nomor yang dilombakan. Hingga saat ini prestasi badminton atlet-atlet Indonesia masih yang terbaik meskipun atlet-atlet berbakat dari negara lain mulai bermunculan. Hal ini menunjukkan bahwa bangsa ini memiliki potensi di cabang olah raga ini. Akan sangat sayang sekali apabila prestasi yang telah dicapai dengan susah payah ini tidak dipertahankan dan di kembangkan lebih lanjut.

Namun pada kenyataan di SD Negeri 104213 Delitua, dari jumlah 36 siswa kelas VI ketika dimintakan memperagakan teknik-teknik dasar permainan badminton, hanya sembilan orang siswa atau sekitar $25 \%$ yang mampu mempraktekkannya. Selebihnya $75 \%$ siswa tidak mampu. Hal ini disebabkan karena selama ini dalam pelaksanaan pembelajaran dikelas untuk mengajarkan teknik-teknik dasar dalam permainan badminton hanya sebatas teori saja. Ketika kegiatan praktek dilapangan, teknikteknik dalam permainan badminton tidak pernah dipraktekkan secara langsung. Kalaupun siswa bermain badminton, mereka hanya bermain bebas sesuka hati mereka tanpa ada bimbingan dari guru olah raga.hal 
tersebut menyebabkan hasil belajar olah raga dalam permainan badminton siswa cenderung menjadi sangat rendah. Penelitian ini bertujuan untuk meningkatkan keterampilan siswa dalam bermain badminton melalui metode driil siswa kelas VI SD Negeri 104213 Delitua tahun pembelajaran 2014/2015.

\section{METODE PENELITIAN}

Penelitian yang penulislakukan ini adalah penelitian tindakan kelas (PTK) yang bertujuan untuk memperbaiki proses pembelajaran yang ada di kelas. Model penelitian tindakan kelas yang dipakai adalah model Lewins. Penelitian ini direncakan dilaksanakan sebanyak 2 siklus, dan dalam setiap siklusnya terdapat kegiatan : 1. Perencanaan, 2. Pelaksanaan, 3. Pengamatan, dan 4. Refleksi.

1. Instrumen Penelitian

Instrumun yang digunakan pada penelitian ini menggunakan teknik nontes berupa unjuk kerja melalui kegiatan observasi, wawancara, dan dokumentasi foto. Instrumen tersebut digunakan untuk melihat peningkatan hasil belajar olah raga badminton setelah mendapatkan metode teknik keterampilan yang diterapkan oleh guru.

\section{a. Lembar Observasi}

Lembar observasi digunakan untuk mengamati dan melihat proses pembelajaran yang dilakukan oleh guru dan aktifitas kemampuan siswa dalam melaksanakan metode teknik keterampilan. Lembar observasi yang dipergunakan ada dua yaitu lembar observasi pengelolaan pembelajaran dan lembar observasi aktifitas siswa.

b. Wawancara

Wawancara dilakukan kepada siswa untuk mengetahui kemampuan mereka dalam hal teknik dasar permainan badminton setelah mendapatkan metode permainan yang dilakukan oleh guru.

\section{c. Dokumentasi Foto}

Dokumentasi foto merupakan bukti aktifitas kegiatan yang telah dilakukan oleh penelit selama melakukan penelitian baik mulai siklus I sampai pada siklus II.

\section{Teknik Analisis Data}

Untuk mengetahui efektivitas suatu metode dalam kegiatan pembelajaran perlu diadakan analisa data. Pada penelitian ini menggunakan teknik analisa deskriptif kualitatif, yaitu suatu metode penelitian yang bersifat menggambarkan kenyataan atau fakta sesuai dengan data yang diperoleh dengan tujuan untuk mengetahui prestasi belajar yang dicapai siswa juga untuk memperoleh respon siswa 
terhadap kegiatan pembelajaran serta aktivitas siswa selama proses pembelajaran

Untuk menganalisis tingkat keberhasilan atau persentase keberhasilan siswa setelah proses belajar mengajar setiap putarannya dilakukan dengan cara memberikan evaluasi berupa tes praktek pada setiap akhir putaran.

\section{HASIL DAN PEMBAHASAN}

Pada saat awal siklus pertama berdasarkan hasil observasi yang dilakukan oleh peneliti dari tiga puluh enam siswa kelas VI SD Negeri 104213 Delitua yang menjadi subjek peneliti, belum seluruhnya mampu memahami dan mempraktekkan 16 teknik dasar dalam permainan badminton. Hal ini memang wajar, sebab dalam mempraktekkan enam belas teknik dasar dalam permainan badminton, memerlukan latihan yang berkesinambungan agar siswa memahami dan dapat mempraktekkan teknik dasar dalam permainan badminton. Hasil observasi pada siklus ke satu dapat dilihat pada grafik di bawah ini.

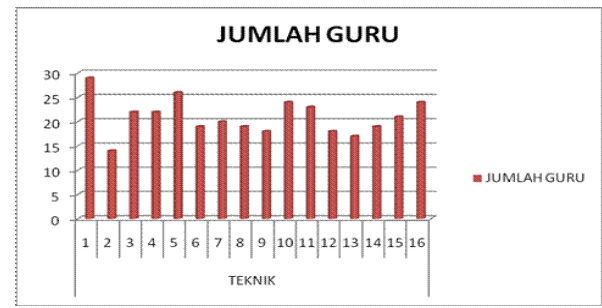

Gambar 1. Kemampuan Siswa

Dalam Mempraktekkan Teknik Dasar Permainan Badminton Siklus I
Untuk teknik 1 ada dua puluh sembilan siswa yang dapat dikategorikan baik atau sekitar $80 \%$, teknik 2 dari tiga puluh enam siswa hanya empat belas orang atau sekitar $38 \%$ yang dikatakan baik selebihnya sekitar $62 \%$ masih belum baik. Teknik 3 adalah sikap dan posisi berdiri di lapangan. Untuk teknik ini dua puluh dua orang atau sekitar $61 \%$ sudah baik. Teknik 4 sama halnya dengan teknik 3 dua puluh dua orang siswa atau sekitar $61 \%$ sudah dapat menguasainya dengan baik. Teknik 5 adalah kemampuan dalam melakukan service, pada teknik 5 ini ada $72 \%$ atau sekitar dua puluh enam siswa sudah dapat melakukan service dengan baik sesuai dengan ketentuan. Untuk teknik 6 sembilan belas siswa atau sekitar 53\% telah dapat menguasai dengan baik. Teknik 7 baru sekitar dua puluh orang siswa atau sekitar 56\% dapat menguasainya sementara $44 \%$ lagi masih belu mampu. Teknik 8 adalah overhead clear, pada teknik ini dari tiga puluh enam siswa hanya sembilan belas orang atau sekitar 53\% yang mampu melakukannya dengan baik, sememntara sisanya $47 \%$ masih belum mampu. Round the head clear adlah teknik 10, untuk teknik ini dua puluh empat siswa atau sekitar $67 \%$ telah mampu melakukannya dengan baik, begitu juga teknik smash yang merupakan teknik ke 11, 67\% atau sekitar dua puluh tiga siswa telah mampu melakukan smash saat 
permainan badminton. Teknik 12 hanya delapan belas siswa atau sekitar 50\% yang dapat menguasainya, begitu juga pada teknik ke 13 kemampuan siswa dalam mengembalikan smash orang lain bisa dikatakan rendah, hanya tujuh belas siswa yang mampu melakukannya, sementara 19 orang siswa yang lain belum mampu. Teknik yang ke-14 adalah backhand, untuk teknik ini ada sekitar sembilan belas orang yang mampu melakukannya atau sekitar 53\%. Teknik yang ke 15 adalah drive, dari tiga puluh enam siswa hanya 58\% atau sekitar dua puluh satu orang yang bisa. Teknik yang terakhir dalam permainan badminton adalah variasi stroke, untuk teknik ini ada dua puluh empat siswa atau sekitar $67 \%$ yang telah mampu melakukannya dengan baik.

Hasil observasi pada siklus kedua terlihat kemampuan dan penguasaan siswa terhadap teknikteknik permainan badminton sudah jauh lebih baik. Hal ini karena peneliti terus memberikan latihan melalui metode teknik keterampilan kepada siswanya sehingga kemampuan siswa pada siklus II jauh lebih meningkat.

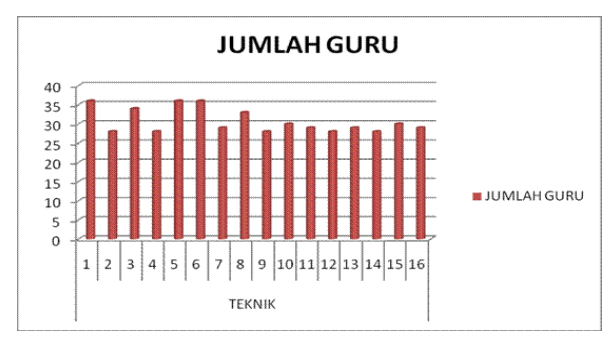

Gambar 2. Kemampuan Siswa dalam Mempraktekkan Teknik Dasar Permainan Badminton Siklus II
Gambar di atas terlihat gambaran kemampuan siswa dalam mempraktekkan teknik-teknik dasar permainan badminton yang dilaksanakan pada siklus II. Untuk teknik 1 seluruh siswa atau $100 \%$ dapat melakukannya dengan kategori baik, teknik 2 dari tiga puluh enam siswa ada dua puluh delapan siswa atau $77 \%$ yang telah dapat melakukannya dengan baik, hanya enam orang atau sekitar $23 \%$ yang masih belum baik. Teknik 3 adalah sikap dan posisi berdiri di lapangan. Untuk teknik ini $100 \%$ siswa atau tiga puluh enam siswa sudah baik. Teknik 4 ada dua puluh delapan siswa atau $77 \%$ yang sudah dapat melakukannya dengan baik, sekitar $23 \%$ masih belum. Teknik 5 dan 6 seluruh siswa atau $100 \%$ telah dapat melakukannya dengan baik. Teknik 7 sudah sekitar dua puluh sembilan siswa atau $80 \%$ sudah dapat melakukannya dengan baik. Teknik 8 adalah overhead clear, pada teknik ini terjadi kemajuan yang cukup tinggi jika dibandingkan dengan siklus I dari tiga puluh enam siswa, sudah tiga puluh tiga siswa atau sekitar $91 \%$ yang dapat melakunnya dengan baik. Round the head clear adalah teknik 10, untuk teknik ini tiga puluh orang siswa atau sekitar $83 \%$ sudah dapat melakukannya dengan baik, begitu juga teknik smash yang merupakan teknik ke 11, $80 \%$ atau sekitar dua puluh sembilan sisa sudah dapat melakukannya. Teknik 12 masih dua e-ISSN 2355-1747 
puluh delapan siswa atau sekitar $77 \%$ yang sudah dapat melakukannya dengan baik, begitu juga pada teknik 13 dua puluh sembilan siswa atau sekitar $80 \%$ yang dapat melakukannya dengan baik. Teknik yang ke 14 adalah backhand, untuk teknik ini ada sekitar dua puluh delapan siswa atau $77 \%$ telah dapat melakukannya dengan baik. Teknik yang ke 15 adalah drive, dari tiga puluh enam siswa $83 \%$ atau sekitar tiga puluh siswa sudah dapat melakukannya dengan kategori baik. Untuk teknik yang terakhir pada teknik permainan badminton adalah variasi stroke, untuk teknik ini ada dua puluh sembilan siswa atau sekitar $80 \%$ yang telah mampu melakukannya dengan baik.

Berdasarkan hasil observasi pada kegiatan mempraktekkan teknik -teknik permainan badminton yang dilaksanakan pada siklus II, terlihat terjadi peningkatan yang cukup baik pada kemampuan siswa jika dibandingkan kegiatan yang dilaksanakan pada siklus I. Terjadi peningkatan dalam kemampuan siswa dalam mempraktekkan teknik-teknik dasar permainan badminton setelah guru menggunakan metode Driil, rata-rata pencapaian komponen teknik permaianan badminton sudah berada di atas 75\%, hal ini memberikan penegasan bahwa penelitian ini hanya dilakukan sampai pada siklus II karena berdasarkan indikator pencapai yang telah ditetapkan, penelitian ini sudah dikatakan berhasil dan tidak perlu dilanjutkan pada siklus berikutnya.

Penelitian Tindakan Kelas yang dilaksanakan di SD Negeri 104213 kecamatan Delitua kabupaten Deliserdang yang merupakan sekolah dimana peneliti bertugas sebagai guru olahraga berstatus negeri, terdiri atas tiga puluh enam siswa kelas VI dan dilaksanakan dalam dua siklus. Ke tiga puluh enam siswa tersebut menunjukkan sikap yang baik dan termotivasi dalam mengikuti kegiatan pembelajaran dengan menggunakan metode teknik keterampilan dalam upaya meningkatkan prestasi olah raga badminton.

Berdasarkan hasil penelitian yang telah dilakukan mulai dari pra siklus, siklus I dan dilanjutkan pada siklus II, terjadi peningkatan kemampuan hasil belajar olah raga pada permainan badminton melalui metode teknik permianan yang dilakukan oleh peneliti. Pada awal penelitian berdasarkan hasil observasi dan wawancara peneliti dengan siswa kelas VI diketahui kemampuan siswa dalam melaksanakan teknik permainan badminton dari tiga puluh enam siswa, hanya sembilan orang siswa atau sekitar $25 \%$ yang mengerti dan dapat melakukan teknik-teknik dasar permainan badminton.

Siklus I dilaksanakan oleh peneliti dengan menggunakan metode teknik keterampilan. Setelah siklus I dilaksanakan peneliti terjadi 
peningkatan rata-rata kemampuan siswa dalam melakukan teknik permaianan.Rata-rata kemampuan siswa dalam melakukan dan mempraktekkan teknik-teknik dasar permaian badminton meningkat menjadi $58 \%$. Hasil ini belum sesuai dengan indikator pencapaian hasil yang ditetapkan pada penelitian ini, maka penelitian ini dilanjutkan pada siklus II.

Siklus II dilaksanakan dengan menggunakan metode teknik permaianan yang telah dirancang oleh peneliti, namun ada beberapa kegiatan pada siklus II yang dirubah oleh peneliti, diantaranya ketika siswa berlatih melakukan teknikTeknik dasar permainan badminton dilakukan dalam kelompokkelompok. Latihan dalam kelompokkelompok ini diharapkan akan terjadi tutor sebaya antar peserta sehingga siswa akan lebih cepat paham dan mengerti dalam melakukan teknik dasar pada permainan badminton. Hasil yang diperoleh pada siklus II ini ternyata jauh luar biasa terjadi peningkatan jika dibandingkan dengan yang dilakukan pada siklus I. Diakhir siklus II terlihat kemampuan rata-rata siswa dalam menerapkan dan mempraktekkan teknik-teknik dasar permainan badminton meningkat. Kalau pada siklus I hasil rata-rata kemampuan siswa dalam mempraktekkan teknik dasar permainan badminton 58\%, maka pada siklus II hasil rata rata tersebut meningkat menjadi $84 \%$, terjadi peningkatan $26 \%$ dari siklus I. Berdasarkan dari hasil rata-rata tersebut, maka penelitian ini dikatakan berhasil karena telah mencapai indikator keberhasilan penelitian dimana dalam indikator tersebut penelitian dikatakan berhasil apabila rata-rata pencapaian siswa terhadap seluruh teknik -teknik dasar permainan badminton sebesar $75 \%$. Tabel peningkatan kemampuan siswa dalam mempraktekkan teknik-teknik dasar permainan badminton dapat dilihat pada tabel di bawah ini:

Tabel 1. Peningkatan Kemampuan Penguasaan Teknik-Teknik Dasar Permainan Badminton

\begin{tabular}{|c|c|c|c|}
\hline No & HASIL & PERSENTASE & KET \\
\hline 1 & $\begin{array}{c}\text { Pra } \\
\text { Tindakan }\end{array}$ & $25 \%$ & $\begin{array}{c}\text { Sangat } \\
\text { rendah }\end{array}$ \\
\hline 2 & Siklus I & $58 \%$ & rendah \\
\hline 3 & Siklus II & $84 \%$ & baik \\
\hline
\end{tabular}

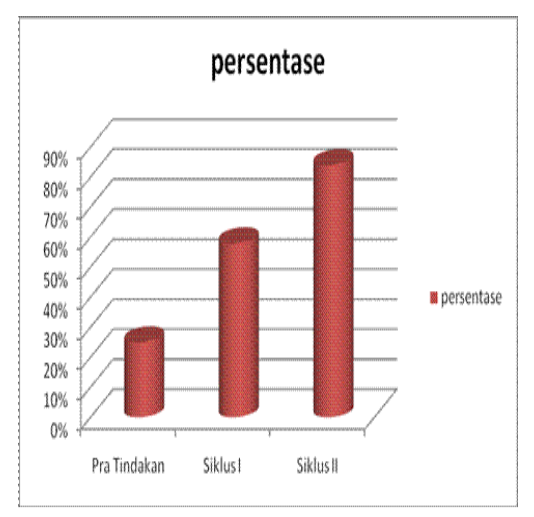

Gambar 3. Peningkatan KemampuanPenguasaan TeknikTeknik Dasar Permainan Badminton 


\section{SIMPULAN}

Dari hasil kegiatan pembelajaran yang telah dilakukan selama dua siklus dan berdasarkan seluruh pembahaan serta analisis yang telah dilakukan dapat disimpulkan sebagai berikut:

1. Pembelajaran olah raga dengan metode Driil dapat meningkatkan keterampilan dalam bermain badminton pada siswa kelas VI SD Negeri 104213 Delitua.

2. Peningkatan prestasi olah raga badminton dapat dilihat dari kemampuan siswa dalam melaksanakan dan mempraktekkan teknik-teknik dasar dalam permainan badminton dimana pada saat pra siklus rata-rata kemampuan siswa hanya $25 \%$, pada siklus I menjadi $58 \%$ dan diakhir siklus II menjadi $84 \%$. Terjadi peningkatan $59 \%$ jika dilihat dari pra siklus, dan dengan rata rata pencapaian kemampuan dalam mempraktekkan teknik dasar permainan badminton $84 \%$ ini telah memenuhi indikator keberhasilan penelitian, maka penelitian ini dikatakan berhasil.

3. Penerapan metode driil dalam pembelajaran olahraga mempunyai pengaruh positif bagi perkembangan psikomotorik siswa kelas VI SD Negeri 104213 Delitua.
DAFTAR RUJUKAN

Arikunto, Suharsimi. 2002. Prosedur

Penelitian Suatu Pendekatan

Praktik. Jakarta: PT. Rineka Cipta.

Engkos, S.R. 1994. Penjaskes. Jakarta: Erlangga.

Husni, Agusta,dkk. 1987. Buku pintar Olahraga . Jakarta: Mawar Gempita.

Muhajir. 1998. Pendidikan Jasmani dan Kesehatan, Untuk SMU Kelas 2. Jakarta: Erlangga.

Slamet, S.R. 1994. Penjaskes 3. Jakarta: Tiga Serangkai.

Suharno. 1986. Ilmu Kepelatihan Olah Raga Yogyakarta: IKIP Yogyakarta.

Syarifuddin, Aib. 1997. Penjaskes 1,2,3. Jakarta: PT. Gramedia Widiasmara Indonesia. 